\title{
Artsen opleiden in een veranderend maatschappelijk veld
}

\author{
J. De Maeseneer
}

\section{Samenvatting}

De vraag naar de kenmerken van het veranderend maatschappelijk veld wordt verschillend beantwoord door artsen, patiënten, politici en sociologen. Artsen leggen vooral het accent op de demografische ontwikkelingen, wijzigingen in de morbiditeit en de nieuwe technologische ontwikkelingen. De patiënt wenst op basis van informatie mee te kunnen beslissen en verwacht van het gezondheidszorgsysteem een flexibele service. Politici hebben aandacht voor kwaliteit van de zorgverlening en proberen het kostenplaatje onder controle te houden. Sociologen geven aan dat we geëvolueerd zijn naar een kennismaatschappij. Belangrijke ontwikkelingen zijn de evolutie naar een meer en meer multiculturele samenleving en de toenemende dualisering door de groeiende informatie-kloof. Al deze ontwikkelingen stellen eisen aan de arts, zowel op vakinhoudelijk vlak als wat betreft de zorgorganisatie. Onderwijskundig blijft het W.G.O.-model van de 'five star doctor' hierbij bijzonder waardevol. Het dient vertaald te worden in een curriculum dat student-georiënteerd, patiënt-gebaseerd, evidence based en gemeenschapsgericht is. De artsopleiding Gent probeert hierop in te spelen via een fundamentele curriculumhervorming. Belangrijke aspecten hierbij zijn: integratie via 'blokken', 'lijnen' en een studium generale. Een belangrijk accent ligt op gemeenschapsgericht onderwijs.

Een aantal actuele discussies met betrekking tot de randvoorwaarden zoals duur van de opleiding en het vormen van 'nieuwe professionals' in de gezondheidszorg verdienen bijzondere aandacht. Voor de opleidingen blijft de uitdaging de veerkracht te hebben om de faculteiten steeds opnieuw aan te passen aan het veranderend maatschappelijk veld en erin te blijven geloven dat studenten in staat zijn om deze nieuwe uitdagingen aan te kunnen.

\section{Inleiding}

De opleiding van artsen moet maatschappelijk relevant zijn: alle medische faculteiten onderschrijven dit vandaag. Maar wat betekent 'maatschappelijk relevant' vandaag en hoe wordt dit onderwijskundig vertaald?

Deze bijdrage vangt aan met een verkenning van het veranderend maatschappelijk veld en dit vanuit het perspectief van artsen, patiënten en sociologen. Vervolgens wordt stilgestaan bij de consequenties van deze veranderingen en de uitdagingen die dit voor de arts van nu en straks mee- brengt. Aansluitend komen de gevolgen die dit alles heeft voor de opleiding van artsen aan de orde waarbij wordt ingezoemd op een aantal actuele debatten.

\section{Het veranderend maatschappelijk veld}

De vraag naar de kenmerken van het veranderend maatschappelijk veld wordt verschillend beantwoord door artsen, patiënten, politici of sociologen. Artsen schuiven klassiek naar voren dat vooral de demografische ontwikkelingen, de wijzigingen in morbiditeit en mortaliteit en de nieuwe technologische ontwikkelingen de essen- 
tie uitmaken van de maatschappelijke veranderingen. We worden allemaal ouder (de eerste mens die 150 jaar wordt is wellicht al geboren; het is maar zeer de vraag of iemand hoopt dat hij of zij deze eerste mens is), het morbiditeits- en mortaliteitspatroon is grondig in evolutie. Tabel 1 geeft een overzicht van de doodsoorzaken voor Vlaanderen in 2001. ${ }^{1}$

Een grondige studie van de doodsoorzaken toont aan dat voor de leeftijdsgroepen tot 29 jaar de belangrijkste doodsoorzaken weinig beïnvloed worden door wat gebeurt in het spreekuur bij het individuele arts-patiënt contact: ongevallen in de privé-sfeer en verkeersongevallen vragen om een maatschappelijke aanpak. Zelfmoord als belangrijkste doodsoorzaak in de leeftijdsgroep van 30 tot 49 jaar voor de mannen en van 30 tot 39 jaar voor de vrouwen stelt de vraag naar de gezondheidstoestand van de samenleving. Doodsoorzaken boven de 50 jaar hebben in een niet onbelangrijke mate te maken met leefstijl (ongezonde voeding, weinig beweging, roken). De rol van de individugerichte curatieve geneeskunde bij de beïn- vloeding van deze doodsoorzaken is wellicht vrij beperkt. Intussen blijft de medische technologie zich verder ontwikkelen: een mooi voorbeeld vormt hier het onderzoek met betrekking tot stamcellen: een zoektocht via Pubmed met als trefwoord 'stem cells' levert twintig artikelen per dag op (in 2001: 7678 artikelen).

Ook de patiënt presenteert zich vandaag anders dan pakweg twintig jaar geleden: de patiënt is beter geïnformeerd. Recent deed de 'reason for encounter' ('Dokter, ik zag op het internet ...') in het spreekuur zijn intrede. De patiënt wenst op basis van informatie mee te kunnen beslissen, hij verwacht van het gezondheidszorgsysteem een flexibele service (en zeker geen wachtlijsten). De verwachtingen van de patiënt worden meer en meer beïnvloed door een gezondheidsideaal dat wordt voorgespiegeld, mede onder invloed van de gezondheidssector zelf (de 'Barbie-pil' maakt je mooier, frisser,... of 'olijfolie als bron voor een lang leven'). Recent werden door Moynihan vraagtekens geplaatst bij de verantwoordelijkheid van medische en farmaceutische industrie bij het aanstu-

Tabel 1. Doodsoorzaken in Vlaanderen (2001).

Doodsoorzaak
Belangrijkste doodsoorzaak naar leeftijd en geslacht

Minder dan 1

$1-4$

5-9

$10-29$

$30-39$

$40-49$

$50-64$

$60-69$

$70-84$

85 en ouder
Verwikkeling van zwangerschap en perinatale periode Ongevallen privé-sfeer

Verkeersongevallen

Zelfmoord

Longkanker

Longkanker

Hart- en vaatziekten
Verkeersongevallen

Zelfmoord

Vrouwen

Ongevallen privé-sfeer

Verkeersongevallen

Ongevallen privé-sfeer

Verkeersongevallen

Borstkanker

Borstkanker

Hart- en vaatziekten

Hart- en vaatziekten

Hartfalen door ouderdom 
ren van de markt via de creatie van nieuwe ziektebeelden ('female sexual dysfunction'). ${ }^{2}$

Politici die kijken naar de weerslag van de maatschappelijke veranderingen op de gezondheidszorg hechten vooral belang aan de kwaliteit van de zorgverlening, de noodzaak aan transparantie en bovenal moet het kostenplaatje onder controle gehouden worden. Een vergelijking België - Nederland maakt duidelijk dat zowel het weinig gestructureerde open marktmodel (met hoofdzakelijk betaling per verrichting) als het gereguleerde model (met globale financiering) problemen kent. In België blijft het moeilijk volumina (en het budget) onder controle te houden, in Nederland zijn er problemen met het onderhouden van de noodzakelijke dynamische flexibiliteit voor een patiëntgericht zorgsysteem.

Sociologen geven aan dat de belangrijkste veranderingen zijn dat we van een samenleving waar industriële massaproductie centraal stond geëvolueerd zijn naar een kennismaatschappij. Deze transitie heeft belangrijke gevolgen op het vlak van verdeling van welvaart, macht en op de aard van sociale interacties. Binnen de geneeskunde kan men zich daar wel iets bij voorstellen: de Codex Medicus als bijbel werd vervangen door 'clinical evidence', via protocollen en richtlijnen dient het handelen van artsen onderbouwd. De kennis die hierbij gehanteerd wordt is niet langer 'authority based' maar 'evidence based'. Klinische ervaring moet het afleggen tegen odds ratio's.

Tezelfdertijd leren sociologen ons dat we meer en meer leven in een risicomaatschappij. ${ }^{3}$ Het gaat hierbij om drie soorten risico's. Ten eerste onderscheidt men ecologische risico's (het belang van de problematiek van voedselveiligheid, treffend geïllustreerd door de dioxinecrisis in België, het belang van water- en luchtvervui- ling, de aandacht voor lawaaihinder rond vliegvelden et cetera). Vervolgens zijn er sociaal-economische risico's (de verontrustende vaststelling dat sociaal economische gezondheidsverschillen blijven toenemen, ook bijvoorbeeld in Scandinavische landen met een uitgebouwd systeem van sociale voorzieningen). Als laatste zijn er individualiseringsrisico's (toenemend aantal alleenstaanden, éénoudergezinnen, de afwezigheid of deficiëntie van sociale netwerken waardoor de organisatie van de mantelzorg steeds moeilijker wordt). Zeker huisartsen en sociaal geneeskundigen worden van dichtbij geconfronteerd met de weerslag van deze risico's op gezondheid en welbevinden.

Toenemende mobiliteit en migratie hebben in de laatste tien jaar de ontwikkeling van een multiculturele samenleving versneld en geïntensiveerd. Ofschoon de gevolgen van mobiliteit en situatie voor de West-Europese landen beperkt zijn, bijvoorbeeld in vergelijking met de migratie in Afrika, blijft onze samenleving het moeilijk hebben om hiermee op een menselijke wijze om te gaan. De multiculturele samenleving is intussen duidelijk aanwezig in de spreekkamer van de arts: in de praktijk van het wijkgezondheidscentrum Botermarkt in Ledeberg tellen we op 4.000 patiënten 55 nationaliteiten. Elk spreekuur wordt op deze wijze een wereldreis: vanuit antropologisch standpunt erg boeiend, maar in de concrete patiëntenzorg niet eenvoudig, bijvoorbeeld op het vlak van arts-patiënt communicatie.

In de post-industriële informatiemaatschappij leven arts en patiënt in nieuwe verbanden: hiërarchische permanente structuren maken plaats voor flexibele tijdelijke netwerken en dit zowel wat betreft de professionele organisatie als in het privé-leven. Gegeven de positie die artsen in de hiërarchie steeds hebben ingeno- 
men, is deze transitie niet evident en vraagt nieuwe attitudes. Al deze ontwikkelingen leiden tot een toenemende dualisering binnen de samenleving. Het overgrote deel (70 à 80\%?) participeert aan de ontwikkeling van kennis, technologie, welvaart. De rest komt in toenemende mate buiten spel te staan. Er zijn indicaties dat het internet de kloof tussen de 'information rich' en de 'information poor' vergroot, eerder dan deze te verkleinen.

Het politieke antwoord op deze maatschappelijke ontwikkelingen (het poldermodel in Nederland en de actieve welvaartstaat in België) verkeert duidelijk in crisis: vastgesteld moet worden dat de politiek de mate waarin ze in staat is om in de samenleving het verbindend vermogen tot stand te brengen, overschat heeft. Vanuit de hulpverlening en met name in de gezondheidszorg kan dit duidelijk vastgesteld worden: hulpverleners en gezondheidswerkers zijn voor een groeiend aantal mensen nog de enige verbinding met de samenleving, het enige signaal dat zij meetellen, dat de maatschappij om hen bekommerd is. Dit schept nieuwe verwachtingen naar de zorgverlening. Tegenover dit toegenomen verwachtingspatroon naar de gezondheidszorg staat de vaststelling dat de sector vanuit de politieke wereld steeds meer onder vuur komt te liggen. Wat zijn de doelstellingen? Worden deze op een efficiënte wijze gerealiseerd? Levert de gezondheidszorg een bijdrage tot meer sociale rechtvaardigheid?

\section{Uitdagingen voor de arts van nu en straks}

De ontwikkelingen in het veranderend maatschappelijk veld stellen duidelijke vragen aan de arts, en dit zowel op vakinhoudelijk vlak als wat betreft de zorgorganisatie. Vakinhoudelijk is het duidelijk dat de ontwikkeling van 'evidence based medicine' een wetenschappelijke binding geeft aan de vroegere vrijheid van diagnose en therapie, en dat de roep om 'evidence based policy' hier een maatschappelijke binding aan toevoegt 4 (de gekozen therapie moet voor zoveel mogelijk mensen zoveel mogelijk jaren met goede levenskwaliteit brengen). Artsen worden mee betrokken bij de discussie rond kosten-effectiviteit en de samenleving verwacht dat zij meewerken aan het evenwicht tussen de individuele aanspraken van de patiënt en de collectieve noden van de bevolking. Alleen door wetenschappelijk onderbouwd en maatschappelijk verantwoord te werken, kunnen artsen bijdragen tot het herstel of behoud van de toegankelijkheid van het zorgsysteem. Dit betekent dat artsen meer en meer zullen functioneren in interdisciplinaire netwerken, waarbij ze meer dan vroeger gericht zullen zijn op hun kerntaken, en waarbinnen subsidiariteit er voor moet zorgen dat iedereen toegang heeft tot verantwoorde zorgverlening met de noodzakelijke kwaliteit voor de meest verantwoorde kostprijs. De situatie is momenteel zeker niet eenvoudig, gegeven de schaarste aan verpleegkundigen, huisartsen, specialisten et cetera. Deze schaarste heeft te maken met een fundamentele maatschappelijke crisis van het zorgberoep, en gaat niet louter om een extrapolatiefout bij de planning van de aantallen artsen en andere zorgverstrekkers. In gesprekken met jongeren stellen we vast dat het 'zorgberoep' niet meer aantrekkelijk is voor hen, en dat jongeren (zowel mannen als vrouwen) vandaag een andere (overigens terechte) keuze maken in de mix tussen privé en professioneel bezig zijn.

\section{Wat betekent dit voor de opleiding van artsen?}

Zowel de beschrijving van het veranderend maatschappelijk veld als de gevolgen hiervan voor de arts van nu en straks, 
maken duidelijk dat een toekomstgerichte opleiding zal dienen uit te gaan van een brede maatschappelijk onderbouwde doelstelling. Het model van de 'five star doctor' van de Wereldgezondheidsorganisatie geeft duidelijk aan wat de kernelementen zijn van deze toekomstvisie (zie tabel 2).

Tabel 2. Toekomstvisie: WHO - five star doctor.

\section{The Five Star Doctor}

- Assess and improve the quality of care;

- Make optimal use of new technologies;

- Promote healthy lifestyles;

- Reconcile individual and community health requirements;

- Work efficiently in teams.

Hoe kan dit vertaald worden binnen het onderwijs? Een aantal grote oriëntaties tekenen zich internationaal af. Binnen innoverende medische faculteiten overal ter wereld, ontstaat stilaan een duidelijk beeld van de kenmerken die een toekomstgerichte opleiding dient te vertonen. In de eerste plaats dient deze opleiding student-georiënteerd te zijn. Dit betekent dat rekening gehouden wordt met de verwachtingen van de student van vandaag, die een grote mate van autonomie wenst om zijn leerproces zelf te kunnen sturen, die 'zappend' opgegroeid is met de gameboy en computer, die op een creatieve wijze met probleemoplossende processen wenst om te gaan. De docent treedt op als begeleider bij het proces van informatie verwerven en verwerken.

Een tweede vereiste van het curriculum is dat het van bij het begin patiënt-gebaseerd is: de hoofdopdracht van de medische opleiding blijft het vormen van artsen die in de patiëntenzorg actief zullen zijn. Een vroegtijdige oriëntatie op het contact met de patiënt werkt motiverend voor het verwerven van noodzakelijke kennis, vaardigheden en attitudes. De opleiding zal op de derde plaats evidence based moeten zijn: niet alleen in de medische inhouden die aan de orde worden gesteld in het onderwijstraject, maar evenzeer in de gehanteerde onderwijskundige methoden dient de wetenschappelijke onderbouwing aanwezig te zijn. Tenslotte dient de artsopleiding ook gemeenschapsgericht te zijn: het is van groot belang dat vanaf de start studenten voortdurend in contact gebracht worden met de concrete samenlevingsproblematiek waarbinnen de gezondheidszorg probeert om, als één van de actoren, antwoorden te formuleren. Het ontstaan van 'community-faculty-partnerships' (samenwerkingsverbanden tussen de medische faculteit en de lokale gemeenschap via projecten op het vlak van onderwijs, dienstverlening en wetenschappelijk onderzoek) is hierbij van groot belang.

\section{Poging tot toepassing: het nieuwe curriculum in de medische faculteit aan de Universiteit Gent}

Op basis van het Visitatierapport uit 1997 heeft in Gent een grondige hervorming van het medisch curriculum plaatsgevonden. Het oude discipline-gebaseerd, sterk theoretisch uitgebouwd curriculum is omgebouwd naar een geïntegreerd project met de ambitie de 'five star doctor' te vormen.

Het nieuwe curriculum bestaat uit blokken. Dit zijn geïntegreerde onderwijsmodules, meestal 4 tot 6 weken durend, waarbinnen een topic vanuit verschillende disciplines wordt benaderd Verder zijn er vier lijnen, die het volledige curriculum doorlopen: de Vaardigheden-lijn, de lijn Probleemoplossen, de lijn Zelfstandig Werk en de lijn Exploratie en Ethiek. Tot slot is er een studium generale dat als 
bedoeling heeft de horizon van studenten te verbreden naar samenleving, cultuur, kunst, politiek et cetera.

Binnen de blokken wordt een mix van leervormen gebruikt: hoorcolleges (sterk beperkt ten aanzien van het oude curriculum), responscolleges, tutorials, oefensessies, probleemgeöriënteerd onderwijs, multidisciplinaire panelgesprekken, (geïntegreerde) klinische lessen, gestructureerde stages, observerende participatiestages, schrijven van papers en het maken van een scriptie. Het eerste jaar is opgebouwd rond 'de cel', eindigend met een blok Infectie en Afweer. Het thema 'veranderend maatschappelijk veld' komt zowel in jaar 1 als jaar 3 onder de aandacht in een blok Gezondheid en Maatschappij. Binnen dit blok werken studenten in jaar 3 gedurende één week aan de 'community diagnosis' van vier oude stadswijken in Gent. Hierbij gaan ze eerst op bezoek bij patiënten die exemplarisch zijn voor de aard van de gezondheidsproblemen binnen de buurt. Vervolgens hebben ze contact met drie hulpverleners betrokken bij deze patiënt, waardoor ze een breder zicht krijgen op het probleem en tevens kennis maken met het hulpverleningsnetwerk rond de patiënt. Deze informatie wordt samen gelegd en geconfronteerd met statistische gegevens in verband met de verschillende wijken: demografie, kwaliteit van het woningbestand, het aantal langdurig werklozen, aantal allochtonen, aanwezigheid van welzijnsvoorzieningen, criminaliteitsstatistieken et cetera.Vanuit deze informatie komen de studenten tot een gemeenschaps-diagnose: twee problemen die volgens hen belangrijk zijn voor de gezondheidstoestand van deze buurt. In de volgende fase formuleren de studenten voorstellen tot oplossing, die op het eind van de week in een publieke zitting worden voorgesteld aan de bevoegde poli- tieke overheden van de stad (burgemeester en wethouders/schepenen). Het belang van deze week is dat de studenten duidelijk leren om gezondheidszorg in een bredere context te zien, en dat ze tevens een bijdrage leveren tot de discussie over concrete problemen in de oude stadswijken in Gent. In het academiejaar 2002-2003 werd deze opdracht interdisciplinair uitgevoerd in een samenwerking tussen studenten geneeskunde en studenten uit de opleiding sociale agogiek. Dit gaf aanleiding tot een boeiende confrontatie van twee 'culturen' op het vlak van benadering van gezondheids- en welzijnsproblemen.

In de lijn rond probleemoplossen worden de studenten vanaf het begin vertrouwd gemaakt met het gebruik van internet als informatiebron, met de principes van evidence based medicine en medische besliskunde. In de lijn Exploratie en Ethiek volgen de studenten vanaf het tweede jaar gedurende drie jaar een gezin waar een baby geboren is en leren op deze wijze zicht te krijgen op ontwikkelings- en opvoedingsprocessen. In de ethische discussies wordt uitvoerig ingegaan op de problemen bij het verzoenen van de aanspraken van het individu met de verwachtingen van de samenleving.

Bij de omvorming van het curriculum is duidelijk geworden dat dit een proces is dat fundamenteel ingrijpt op alle niveaus van een medische faculteit: het hertekent fundamenteel de rol van docenten, het vormt een uitdaging voor de instelling om nieuwe vormen van organisatie, structurering en informatiedoorstroming te realiseren. Momenteel is het nieuwe curriculum in zijn vierde jaar en wordt met spanning uitgekeken naar de toekomst: vormt dit nieuwe curriculum inderdaad andere artsen, die de uitdagingen van de $21^{\text {ste }}$ eeuw zullen aankunnen? 


\section{Enkele actuele discussies: duur van de opleiding? de 'nieuwe professionals'?}

Veel belangrijker dan de door Europa opgelegde implementatie van de bachel or-master structuur is het debat rond de duur van de artsopleiding. Is het nog langer verantwoord om deze opleiding voortdurend te verlengen (momenteel is de totale duur van de opleiding van een specialist vrij snel 13 jaar)? Figuur 1 illustreert de discussie. In deze figuur stelt de bovenste balk de huidige situatie voor, de onderste balk de gewenste situatie. Enerzijds wordt voorgesteld om de basisopleiding zo kort mogelijk te houden en de totale opleiding te beperken tot 10 jaar. De achterliggende motivering is dat een te lange opleiding een infantiliserende werking heeft, doordat men tijdens een opleiding geen eindverantwoordelijkheid krijgt. Het is toch merkwaardig vast te stellen dat enkele jaren geleden de manager van het jaar in Vlaanderen 28 jaar was, een leeftijd waarop een chirurg in opleiding (als alles goed gaat), zijn eerste appendix zelfstandig heeft verwijderd. Figuur 1 geeft tevens aan dat er wellicht gestreefd moet worden naar een andere mix tussen theorie en praktijk: het huidige Z-vormig model wordt wellicht beter vervangen door een olievlekmodel waarbij voortdurend theorie en praktijk inter-ageren, en dit niet alleen tijdens de basisopleiding, maar ook in de huisarts- en specialistenopleiding. Op deze wijze wordt de oude onvruchtbare dichotomie tussen theorie en praktijk (waar het er vaak 'anders' aan toe ging) overstegen.

Een tweede belangrijke discussie die actueel gevoerd wordt is die over de vorming van 'nieuwe professionals' en hun rol in de gezondheidszorg. Vanuit de patiënt wordt in verband met deze discussie vooral gewezen op de nood aan begeleiding, integratie, 'advocacy' in een steeds complexer wordend gezondheidszorgsysteem. Vanuit de paramedici klinkt duidelijk de wens tot professionele doorgroei in patiëntgebonden werk. Vanuit de artsen klinkt de verzuchting om zich meer te richten op hun kerntaken en een aantal van hun actuele taken te delegeren. Momenteel zijn vele definities, invullingen en modellen in ontwikkeling: de physician assistant, de (advanced) nurse practitioner en voor de huisartsgeneeskunde de praktijkondersteuner. Het lijkt belangrijk dat medische faculteiten zich in overleg met andere opleidingsinstituten bezinnen om het huidige, weinig overzichtelijke aanbod van opleidingen terzake te stroomlijnen.

Figuur 1. Opleiding arts: duur en mix theorie-praktijk.

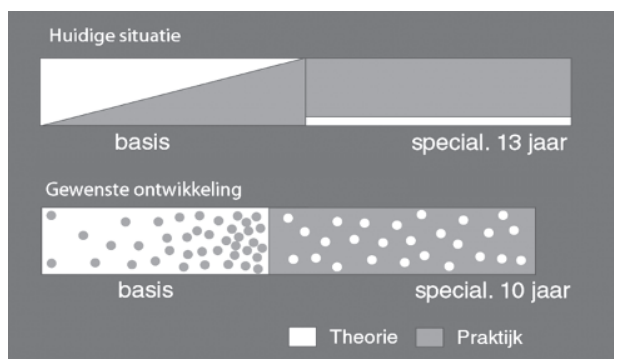

\section{Tenslotte}

Als medische faculteiten een antwoord willen geven op het veranderend maatschappelijk veld en kunnen beantwoorden aan de verwachtingen die gesteld worden aan de arts van nu en straks, dan dienen ze meer actief te participeren in het maatschappelijk debat rond ontwikkelingen in de gezondheidszorg. Immers, het is een illusie om een 'five star doctor' te vormen, wanneer er binnen het gezondheidszorgsysteem niet de noodzakelijke randvoorwaarden vervuld zijn om de kennis, de vaardigheden en attitudes van deze arts maximaal tot ontwikkeling te laten 
komen in het belang van een kwaliteitsvolle zorgverstrekking. Faculteiten zullen zich meer maatschappelijk moeten profileren, ook in soms moeilijke debatten zoals het zorg verlenen in multiculturele context. Het dient duidelijk te zijn dat niet openstaan voor andere culturen geen optie is als dokter. De uitdagingen voor de toekomst zijn niet eenvoudig. Tabel 3 geeft een overzicht van wat van de medische professie in het nieuwe millennium wordt verwacht. 5

Tabel 3. Verwachtingen t.a.v. de medische professie.

\section{Medical Professionalism in the new millenium}

\section{a physician's charter}

\section{Commitment to:}

- Professional competence;

- Honesty with patients;

- Patients' confidentiality;

- Maintaining appropriate relationships with patients;

- Improving quality of care;

- Improving access to care;

- A just distribution of finite resources;

- Scientific knowledge;

- Maintaining trust by managing conflicts of interest

- Professional responsibilities.
Het is geen eenvoudige opdracht. Als verantwoordelijken voor de medische opleiding zullen we nood hebben aan een brede maatschappelijke visie, aan de veerkracht om onze faculteiten steeds opnieuw aan te passen en aan vertrouwen dat studenten in staat zijn om deze nieuwe uitdagingen aan te kunnen.

\section{Literauur}

1. Anoniem. Vlaamse Regionale Indicatoren 2001. Brussel: Ministerie Vlaamse Gemeenschap; 2002.

2. Moynihan R. The making of a disease: female sexual dysfunction. British Medical Journal 2003;326:45-7.

3. Beck U. Risk society: towards a new modernity. London: Sage Publications; 1992.

4. De Maeseneer J. Professionele autonomie: naar een maatschappelijk zinvolle invulling. Huisarts $\mathrm{Nu}$ 1998;27:203-5.

5. Anonymous. Medical professionalism in the new millennium: a physicians' charter. Lancet 2002;359:250-522.

De auteur:

Prof. dr. J. De Maeseneer is als gewoon hoogleraar Huisartsgeneeskunde verbonden aan het Universitair Ziekenhuis Gent, België.

Correspondentieadres:

Prof. dr. J. De Maeseneer, Universitair Ziekenhuis $1 \mathrm{~K} 3$, De Pintelaan 185, B-9000 Gent, België, jan.demaeseneer@ugent.be.

Bron: The Lancet 2002;359:520-22

\section{Summary}

The questions about the characteristics of the changing society get different answers from doctors, patients, politicians and sociologists. Physicians emphasize the demographic development, the changing morbidity-pattern and the new technological developments. Patients want to participate in the care process and expect a flexible service from the health care system. Politicians look for the quality of health care and try to contain costs. Sociologists analyse the evolution towards a knowledge-society. Important developments are the increasing multicultural society and the increasing dualisation, including the growing information-gap. All these developments confront the physician with challenges, both at the level of the content of the discipline and at the level of health care organisation. The WHO-model of the 'five star doctor' remains a valuable concept. It has to be translated into a curriculum that is student-oriented, patient-based, evidence based and community-oriented. The training of doctors in Ghent tries to implement this in a fundamental curriculum reform. Important aspects are: integration by 'units', 'lines', a studium generale and an important emphasis on community-oriented teaching.

Some actual discussions about the duration of the training and the appearance of 'new professionals' in the health care system need attention. For the training programs, the challenge remains to find the necessary energy to adapt faculties to the changing society and to remain confident that students are able to cope with the new challenges. 